\title{
Ethnomathematics: Graph of Architecture Masjid Agung Kediri
}

\author{
Elly Susanti ${ }^{1}$, Nanda Mustagfirotul Ulya ${ }^{2 *}$, Muhammad Hasan Asnawi ${ }^{3}$, Fachrur \\ Rozi $^{4}$
}

1,4 Jurusan Matematika, Universitas Islam Negeri Maulana Malik Ibrahim Malang, Indonesia

${ }^{2,3}$ Magister Pendidikan Matematika, Universitas Islam Negeri Maulana Malik Ibrahim Malang, Indonesia

${ }^{*}$ Corresponding author. Email: nandaulya09@gmail.com

\begin{abstract}
This study aims to explore and identify the objects of architecture and ornaments Masjid Agung Kediri. In this study, the researcher used qualitative research with an ethnography approach. The instrument of this research is human instruments. The researcher is a primary instrument. As qualitative research with an ethnographic approach, the instrument of this study is the human instrument, the researcher as a primary instrument that can not be changed to someone else. The result of this research indicates that the shape, architecture, and ornaments Masjid Agung Kediri have ethnomathematics connecting with graph concept, such as mosque pillars contains line graph concept denoted by $P_{14}$, prominent buttress contain cycle graph concept denoted by $C_{4}$, ceiling contains cycle graph concept denoted by $C_{8}$, ornaments contain wheel graph concept denoted by $W_{16}$, decorative lights with three levels contain star graph concept in the first level denoted by $S_{25}$, the second level denoted by $S_{13}$, and the third level denoted by $S_{7}$.
\end{abstract}

Keywords: architecture, Masjid Agung Kediri, graph.

\section{INTRODUCTION}

Mathematics has close connections with culture, yet many people still view mathematics as a subject far from the culture in everyday life [1]. Math also has a critical role in solving problems that exist in daily life, for example, counting, proving, measuring, etc. [2]. Discussion of Mathematics in daily life related to culture is often called ethnomathematics [3]. It is proven by Alangui [4] that ethnomathematics succeeded in setting up a relationship between mathematics and the reality of society. Ethnomathematics is defined as the particular ways used by some particular cultural groups or societies in mathematical activities. The math activity is a process of abstraction from experience in daily life into mathematics, including grouping activities, counting, measuring, designing buildings or tools, making patterns, explaining, and so on [5]. Even ethnomathematics makes local culture a starting point for learning mathematics [6].
In Mathematics, there is a function to develop reasoning skills through investigation, exploration, and experiment as a problem-solving tool through the mindset and mathematical models. Also, many concepts and theories are very helpful and useful in human life [2]. The concepts contain Javanese culture by Ethnomathematics: Exploration in Javanese culture [7] and Ethnomathematics in Saaknese architecture [8]. The concepts contained in a building, such as research conducted by Puniarti with Ethnomathematics: Exploration of A mosque Building and Its Ornaments [9]. This study discusses the ornamental forms of the building of a mosque which has a geometry concept. Other researchers who researched about mosque buildings, as Matematika Keislaman: Identifikasi Penggunaan Konsep Matematika pada Masjid Roudhotul Muchlisin di Jember [10] dan Etnomatematika pada Masjid Muhammad Cheng Hoo Jember Sebagai Bahan Pembelajaran [11], etc. So, it's possible when the research was conducted in Masjid Agung Kediri.

Masjid Agung Kediri has a very unique mosque archirecture. This mosque has 49 meters minaret and a 
fountain in front of the mosque. The mosque combines the style of world mosques. The large pillars in the mosque look like the Foundation of Islamic Center mosque in Thailand. Meanwhile, the large windows and walls depict European and Turkish styles. In addition to being oriented to the world mosque, Masjid Agung Kediri still incorporates elements of the Indonesian archipelago, namely Joglo-roof. Those are arranged crosswise, so when viewed from below, the shape resembles eight stars [12]; the architectures, cultural context, and graph concept [13].

$G$ graph is a pair $(V(G), E(G))$ with $V(G)$ is a set whose elements are called vertices, and $E(G)$ is a set of paired vertices, whose elements are called edges. Let $G=(V, E)$ be a graph. For an edge $u v$, we denote $e=(u, v), u$ and $v$ are end vertices of the edge $u v$, and the edge $u v$ is said to be incident on $u$ as well as on $v$. Two vertices $u$ and $v$ are said to be adjacent if $u v$ is an edge [14].

Let $v$ is a vertex in $G$ graph, The degree of a vertex $v$ in a graph $G$ is the number of vertices in $G$ that are adjacent to $v$. Degree of a vertex can be used in determining kinds of unique graphs, such as line graph, cycle graph, wheel graph, and star graph. For example, the line graph with $n$ vertex is denoted by $P_{n}$ consists of two vertexes with one degree, $n-2$ vertex with two degrees, and $n-1$ edge. A cycle graph with $n$ vertex denoted by $C_{n}$ is a graph whose every vertex has two degrees and has the same number of vertex and edge. Wheel graph with $n$ vertex denoted by $W_{n}$ is formed by cycle graph with $n \geq 3$ and connects the new vertexes to each $n$ in $C_{n}$. Finally, the Star graph with $n$ vertex denoted by $S_{n}$ is a graph with one vertex with $n-1$ degree and others one degree [14].

Based on the explanation, it is essential to conduct more in-depth research not only on geometry concepts but also on buildings, ornaments, and architecture in graph concepts. Therefore, the researcher raised the topic of ethnomathematics: graph of architecture Masjid Agung Kota Kediri.

\section{METHOD}

In this paper, the researcher used qualitative research with an ethnography approach. The instrument of this research is a human instrument. The researcher is a primary instrument. This research only discusses the graph concept.

\section{RESULT AND DISCUSSIONS}

Based on observation and exploration in Masjid Agung Kediri, this mosque has unique characteristics such as pillars like Thailand mosque, large windows like European buildings, and roof like joglo in Java. The result of ethnomatematics explorasion in Masjid Agung Kediri as follows:

\subsection{Mosque Pillars}

Figure 1 is mosque pillars. There are 14 pillars like zigzag and connect each other. Based on the Figure1, let pillars as vertexes and the connection between pillars as edge. So it will form a graph in Figure 2.

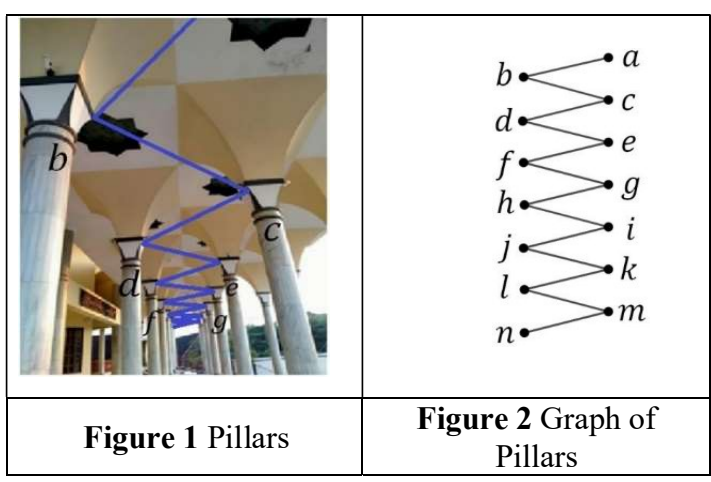

$$
\begin{aligned}
& V(\text { pillar })=\{a, b, c, d, e, f, g, h, i, j, k, l, m, n\} \\
& E(\text { connection }) \\
& =\left\{\begin{array}{c}
a b, b c, c d, d e, e f \\
f g, g h, h i, i j, j k, k l, l m, m n
\end{array}\right\}
\end{aligned}
$$

Based on the definition of graph that does't contain double edge, so Figure 4 is a graph. Figure 4 has 14 vertexs, 13 edges, and degree of each vertex is $\operatorname{deg}(a)=1, \operatorname{deg}(b)=2, \operatorname{deg}(c)=2, \operatorname{deg}(d)=$ $2, \operatorname{deg}(e)=2, \operatorname{deg}(f)=2, \operatorname{deg}(g)=2, \operatorname{deg}(h)=$ $2, \operatorname{deg}(i)=2, \operatorname{deg}(j)=2, \operatorname{deg}(k)=2, \operatorname{deg}(l)=$ $2, \operatorname{deg}(m)=2$, and $\operatorname{deg}(n)=1$. From the explanation, we got that the number of vertex $n=14$, two vertexs have 1 degree ( $a$ and $n), 12$ vertexs have degree $2(12=n-2)$, and 13 edges $(13=$ $n-1)$. Based on definition of line graph [6], so Figure 2 is line graph denoted by $P_{14}$.

\subsection{Main Buttress}

Figure 3 is the mosque buttress. There are four connected main buttresses. Let the buttress as vertexes and the connection as edge. So it will form a graph in Figure 4. 


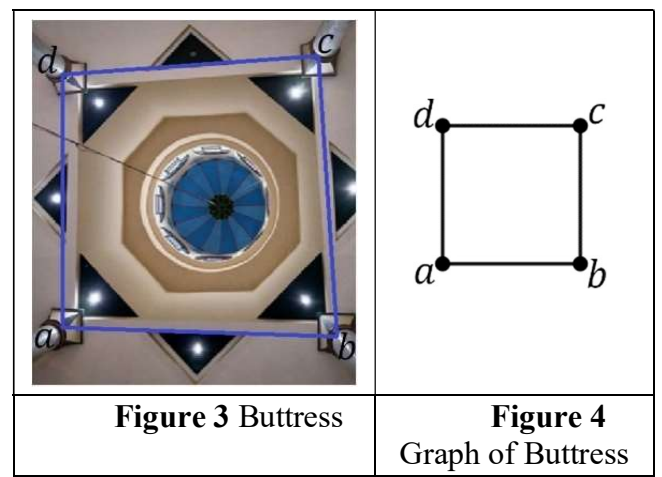

$V($ pillar $)=\{a, b, c, d\}$

$E($ connection $)=\{a b, b c, c d, d a\}$

Based on the definition of a graph that doesn't contain a double edge, Figure 4 is a graph. Figure 4 has 4 vertexes, 4 edges, and degree of each vertex is $\operatorname{deg}(a)=2, \operatorname{deg}(b)=2, \operatorname{deg}(c)=2, \quad$ and $\operatorname{deg}(d)=2$. From the explanation, we got that the number of vertex $n=4$, the number of edges are 4 , and every vertex has the same number of degrees. Based on the definition of the Cycle graph [6], so Figure 4 is a Cycle graph denoted by $C_{4}$.

\subsection{Ceilings}

Figure 5 is mosque ceilling. There are 8 angels and 8 connections. Let the angels as vertexs and the connections as edge. So it will form a graph in Figure 6.

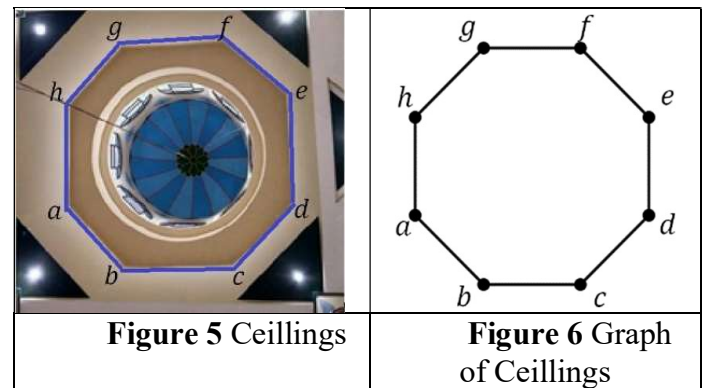

$V($ angel $)=\{a, b, c, d, e, f, g, h\}$

$E($ connections $)=\{a b, b c, c d, d e, e f, f g, g h, h a\}$

Based on the definition of a graph that doesn't contain a double edge, Figure 6 is a graph. Figure 6 has 8 vertexes, 8 edges, and degree of each vertex is $\operatorname{deg}(a)=2, \operatorname{deg}(b)=2, \operatorname{deg}(c)=2, \operatorname{deg}(d)=$ $2, \operatorname{deg}(e)=2, \operatorname{deg}(f)=2, \operatorname{deg}(g)=2, \quad$ and $\operatorname{deg}(h)=2$. From the explanation, we got that the number of vertex $n=8$, the number of the edge is 8 , and every edge has the same degree. Based on the definition of the Cycle graph [6], so Figure 6 is a Cycle graph denoted by $C_{8}$.

\subsection{Ornaments}

Figure 7 is mosque ornaments. There is a center that connects with the angels. Let the center and the angels as vertex and the connection as edge. So it will form a graph in Figure 8.

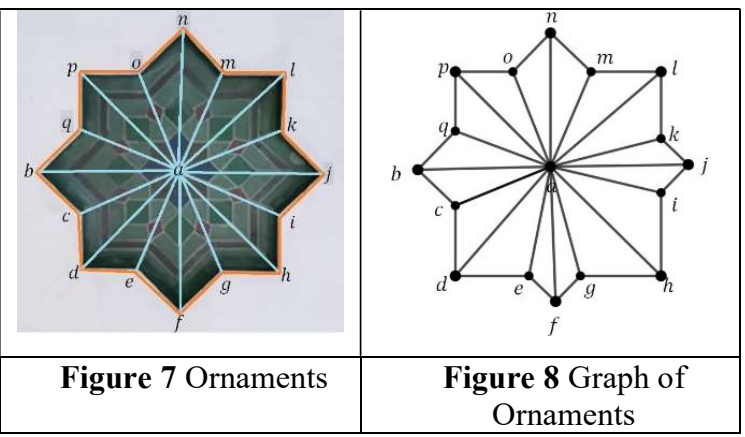

$V(G)=\{a, b, c, d, e, f, g, h, i, j, k, l, m, n, o, p, q\}$

$E(G)$

$=\left\{\begin{array}{c}a b, b c, c d, d e, e f, f g, g h, h i, i j, j k, k l, \\ l m, m n, n o, o p, p q, a b, \\ a c, a d, a e, a f, a g, a h, a i, a j, a k, a l, a m, \\ a n, a o, a p, a q\end{array}\right\}$

Based on the definition of a graph that doesn't contain a double edge, Figure 8 is a graph. Figure 8 has 17 vertexes and 32 edges. So the number of vertexes is $n+1=16+1=17$, and the number of the edge is $2 \times n=2 \times 16=32$. Based on the definition of wheel graph [6], so Figure 8 is a Cycle graph denoted by $W_{16}$.

\subsection{Decorative Lights}

Decorative lights have three levels. Figure 9 is the first level of decorative lights. If we look at the detail, every lamp has a connection with the prop lamp. Let the lamp and the prop as the vertex, and the connection is the edge. So it will form a graph in Figure 10. 


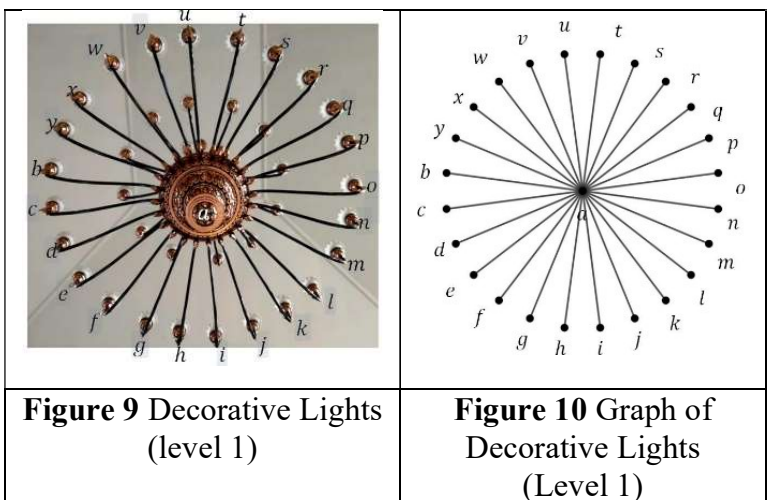

$$
\begin{aligned}
& V(G)=\left\{\begin{array}{c}
a, b, c, d, e, f, g, h, i, j, k, l, m, \\
n, o, p, q, r, s, t, u, v, w, q, y
\end{array}\right\} \\
& E(G)=\left\{\begin{array}{c}
a b, a c, a d, a e, a f, a g, a h, a i, \\
a j, a k, a l, a m, a n, a o, a p, a q, \\
a r, a s, a t, a u, a v, a w, a q, a y
\end{array}\right\}
\end{aligned}
$$

Based on the definition of graph that does't contain double edge, so Figure 10 is a graph. Figure 10 has 25 vertexs, 24 edges, and degree of each vertex is $\operatorname{deg}(a)=24, \operatorname{deg}(b)=1, \operatorname{deg}(c)=$ $1, \operatorname{deg}(d)=1, \operatorname{deg}(e)=1, \operatorname{deg}(f)=1, \operatorname{deg}(g)=$ $1, \operatorname{deg}(h)=1, \operatorname{deg}(i)=1, \operatorname{deg}(j)=1, \operatorname{deg}(k)=$ $1, \operatorname{deg}(l)=1, \operatorname{deg}(m)=1, \operatorname{deg}(n)=1, \operatorname{deg}(o)=$ $1, \operatorname{deg}(p)=1, \operatorname{deg}(q)=1, \operatorname{deg}(r)=1, \operatorname{deg}(s)=$ $1, \operatorname{deg}(t)=1, \operatorname{deg}(u)=1, \operatorname{deg}(v)=1, \operatorname{deg}(w)=$ $1, \operatorname{deg}(x)=1$, and $\operatorname{deg} y=1$. From the explanation, we got that number of vertex is $n=25$, number of edge is 24 , one vertex has 24 degree $(a)$ and others have one degree. Based on the definition of Star graph [6], so Figure 10 is Star graph denoted by $S_{25}$.

Figure 11 is the second level of decorative lights. It's same as the first level. So it will form a graph in Figure 12.

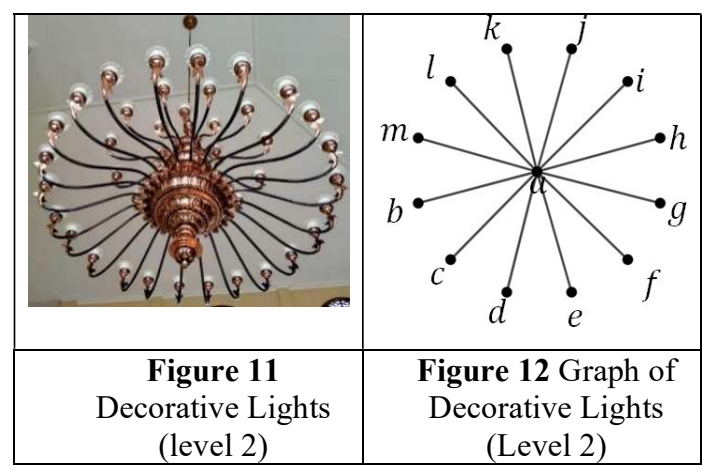

$V(G)=\{a, b, c, d, e, f, g, h, i, j, k, l, m\}$

$E(G)=\left\{\begin{array}{c}a b, a c, a d, a e, a f, a g, \\ a h, a i, a j, a k, a l, a m\end{array}\right\}$

Based on the definition of graph that does't contain double edge, so Figure 12 is a graph. Figure 12 has 13 vertexs, 12 edges, and degree of each vertex is $\operatorname{deg}(a)=12, \operatorname{deg}(b)=1, \operatorname{deg}(c)=$ $1, \operatorname{deg}(d)=1, \operatorname{deg}(e)=1, \operatorname{deg}(f)=1, \operatorname{deg}(g)=$ $1, \operatorname{deg}(h)=1, \operatorname{deg}(i)=1, \operatorname{deg}(j)=1, \operatorname{deg}(k)=$ $1, \operatorname{deg}(l)=1, \quad \operatorname{dan} \operatorname{deg}(m)=1$. From the explanation, we got that number of vertex is $n=13$, number of edge is 12 , one vertex has 12 and others have one degree. Based on the definition of Star graph [6], so Figure 12 is Star graph denoted by $S_{13}$.

Figure 13 is the third level of decorative lights. It's the same as the second level. So it will form a graph in Figure 14.

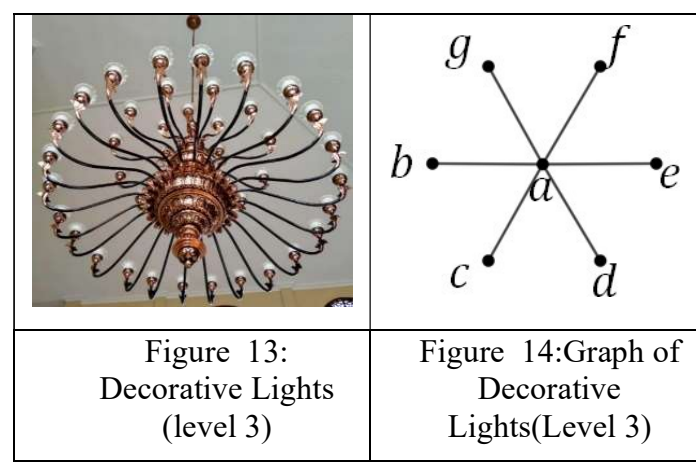

$V(G)=\{a, b, c, d, e, f, g\}$

$E(G)=\{a b, a c, a d, a e, a f, a g\}$

Based on the definition of graph that does't contain double edge, so Figure 14 is a graph. Figure 14 has 7 vertexs, 6 edges, and degree of each vertex is $\operatorname{deg}(a)=6, \operatorname{deg}(b)=1, \operatorname{deg}(c)=1, \operatorname{deg}(d)=$ $1, \operatorname{deg}(e)=1, \operatorname{deg}(f)=1, \operatorname{dan} \operatorname{deg}(g)=1$.

From the explanation, we got that number of the vertex is $n=7$ number of the edge is 6 , one vertex has 6 degrees, and others have one degree. Based on the definition of the Star graph [6], so Figure 14 is a Star graph denoted by $S_{7}$.

\section{CONCLUSION}

Based on the discussion, it's found some shapes, architecture, and ornaments Masjid Agung Kediri have ethnomathematics connecting with graph concept, such as mosque pillars containing line graph concept $\left(P_{14}\right)$. Prominent buttress contains cycle 
graph concept $\left(C_{4}\right)$. The ceiling contains cycle graph concept $\left(C_{8}\right)$. Ornaments contain wheel graph concept $\left(W_{16}\right)$, decorative lights with three levels contain star graph concept in the first level $\left(S_{25}\right)$, the second level $\left(S_{13}\right)$, and the third level $\left(S_{7}\right)$. However, graph concepts and other mathematics concepts still need to be explored more in further research.

\section{REFERENCES}

[1] R. C. I. Prahmana \& U. D’Ambrosio, "Learning Geometry and Values from Patterns: Etnomathematics on the batik patterns of Yogyakarta, Indonesia". Journal of Mathematics Education. 11(3) (2020) pp. 439-456.

[2] Jannah, Etnomatematika pada Pendidikan, Jakarta: Pres Nusantara, 2019.

[3] Muklisin, 2020, Budaya dalam Keilmuan Matematika, Bandung, 2020.

[4] W. V. Alangui, 2010, Stone walls and water flows: Interrogating cultural practice and mathematics, Doctoral Dissertation. Auckland: University of Auckland.

[5] D. Ary, L. C. Jacobs, \& A. Razavich, 1976. Pengantar Penelitian Pendidikan. Terjemahan oleh Arief Furchan. 1982. Surabaya: Usaha Nasional.

[6] W. Widada, D. Herawaty, and A. N. M. T. Lubis, "Realistic mathematics learning based on the ethnomathematics in Bengkulu to improve students ' cognitive level Realistic mathematics learning based on the ethnomathematics in Bengkulu to improve students ' cognitive level," J. Phys. Conf. Ser., 1088(1) (2018) pp. 1-8.
[7] I. Risdayanti, \& R. C. I. Prahmana, "Ethnomathematics: Exploration in Javanese culture", IOP Conf. Series: Journal of Physics: Conf. Series 943 012032, 2017

[8] S. Supiyati, F. Hanum, \& Jailani, "Ethnomathematics in Saaknese architecture", Journal of Mathematics Education, 10(1) (2019) pp. 47-58.

[9] T. Puniarti, Turmudi, \& D. Suhaedi, "Ethnomathematics: Exploration of A Mosque Building and Its Ornaments", Journal of Physics, Vol 1521, 2020

[10]Muklisin, Budaya dalam Keilmuan Matematika. Bandung, 2020

[11] Qoobah, Bangunan Arsitektur Kubah Masjid Agung Kota Kediri. Surabaya: Hasanah Press, 2016

[12]M. Ascher, "Graphs in Cultures: A Study in Ethnomathematics", Historia Mathematics, 1988, 201-227

[13]S. Supiyati, F. Hanum, \& Jailani, "Ethnomathematics in Saaknese architecture", Journal of Mathematics Education, 10(1) (2020) 47-58.

[14] G. Chartrand, L. Lesniak, \& P. Zhang, Graphs and Digraphs. Direct (6th ed.). Florida: CRC Press, 2016. 